\title{
EFFECT OF CHRONIC ORAL ZINC ADMINISTRATION ON SERUM-PROLACTIN LEVEL IN CHRONIC RENAL FAILURE PATIENTS
}

\author{
By \\ Hafez, T. A.; Selim, M. I.; \\ Said, M. A. and Zahran, M. A. \\ From \\ Medical Biochemistry Department, Faculty of Medicine Mansoura University \\ Received for Puplication : 19/5/1992.
}

\section{INTRODUCTION}

One of the most common endocrine disturbances in chronic renal failure patients is hyperprolactinaemia. Several investigators have noted an association between elevated prolactin level and sexual dysfunction in chronic renal fai lure men (Franks et al, 1978; Gomez et al, 1980; Gura et al, 1980).

Supraphysiological concentrations of prolactin are often associated with hypogonadal function. In women, initially there is a shortening of the luteal phase, subsequently anovulation, oligomenorrhea or amenorrhea and infertility occur. In men, diminished libido, impotence, gynaecomastia, and infertility occur (Thorner and Besser, 1978; Werber et al, 1985).

Zinc deficiency is also a common finding in chronic renal failure patients undergoing haemodialysis (Mahaian et al, 1979) and a strong negative correlation was found between serum prolactin and zinc levels in these patients (Mahajan et al, 1985; Hafez et al, 1990).

The effect of oral zinc administration on serum prolactin level and sexual function is a matter of controversy. Brook et al (1980) and Zetin \& Stone (1980) failed to show any benificial effect of zinc administration. However, Antoniou et al (1977) and Mahajan et MANSOURA MEDICAL JOURNAL 
al (1982) reported that the normalization of serum zinc level was associated with striking improvement in sexual function.

These discrepant results lead us to study the effect of oral zinc administration on serum prolactin level and sexual function in chronic renal failure men.

\section{MATERIALS AND METHODS}

Fourteen male patients with chronic renal failure gave their informed consent to participate in this study. Their ages range from 32 to 54 years. They were maintained on chronic haemodialysis three times a week for 1 to 2 years in Mit-Ghamer General Hospital. All were given $400 \mathrm{mg}$ zinc sulphate (equivalent to $5 \mathrm{mEq}$ zinc) per day orally for four months.

For comparison, fourteen healthy males matching for age were selected as a control group. Neither the patients nor the controls were receiving any medications known to affect serum prolactin or zinc levels.

Vol. 22, No. 1 \& 2 Jan. \& April 1992
Blood samples were drawn from control group and from chronic renal failure group before and after zinc administration 2 hours before haemodialysis and 24 hours after the last zinc administration.

Blood samples were analysed for serum zinc and prolactin levels. Serum zinc was measured by absorption spectroscopy against a reference standard according to the method of Fernandez and Khan (1971) using Pye Unicam SP 1900 Atomic Absorption. Serum prolactin was measured by enzyme-linked immunosorbent assay (ELIZA) using Eurogenetics Prolactin Quantitative Kit supplyed by Eurogenitics N.V. Belgium. Also. the patients were asked for symptoms of sexual dysfunction before and after zinc administration.

All values were represented as mean \pm SEM. The significance of the differences between groups was determind by Student's $T$ test and ths significance of differences before and after zinc administration was determined by paired Student's $T$ test 
$P<0.05$ is considered significant.

\section{RESULTS}

Before zinc administration, serum prolactin level in chronic renal failure men $(31.74 \pm 2.61 \mathrm{ng} / \mathrm{ml})$ showed a highly significant increase $(P<0.001)$ than that in normal control group $(15.87 \pm 1.29 \mathrm{ng} / \mathrm{ml})$ as shown in table 1 and figure 1 . Also, the mean serum zinc level in chronic renal failure men $(10.03 \pm 0.47 \mathrm{umol} / \mathrm{L})$ showed a higly significant decrease $(P<0.001)$ than that in normal control group $(18.28 \pm 1.09 \mathrm{umol} / \mathrm{L})$ as shown in table 2 and figure 2.

After zinc administration, serum prolactin level in chronic renal failure men $(2001 \pm 16 \mathrm{ng} / \mathrm{ml})$ was significantly higher $(P<005)$ than that in control group as shown in table 1 and figure 1. On the other hand, serum zinc level in chronic renal failure men (16 $96 \pm 0.98 \mathrm{umol} / \mathrm{L})$ was insignificantly different $(P>0.05)$ from that in control group as shown in table 2 and figure 2.

Comparison of serum prolactin lev- els in chronic renal failure men before and after zinc administration by paired Student's $T$ test revealed a highly significant decrease $(P<0.001)$ in its level after zinc administration $(20.01 \pm 1.6$ vs $31.74 \pm 2.61 \mathrm{ng} / \mathrm{ml}$ ) as shown in table 3 and figure 1 . On the other hand serum zinc level in chronic renal failure men showed a highly significant increase $(P<0.001)$ after zinc administration (16.96 0.86 vs $10.03 \pm 0.47$ umol/L) as shown in table 4 and figure 2.

Also, study of sexual dysfunction symptoms showed improvement in libido, impotence, frequency of intercourse and gynaecomastia after zinc administration as shown in table 5 .

\section{DISCUSSION}

One of the most common endocrine disturbances in chronic renal failure patients is hyperprolactinaemia with its sequele as diminished libido, impotence, gynaecomastia and infertility. This hyperprolactinaemia may arise from decreased metabolic clearance of prolactin (Lim et al, 1970). Probably more important than imMANSOURA MEDICAL JOURNAL 
paired clearance in the genesis of hyperprolactinaemia is increased autonomous production of prolactin due to disinhibition of pituitary lactotrophes (Comez et al, 1980; Sievertsen et al, 1980).

The fact that hyperprolactinaemia does not improve with haemodialysis suggests that hyperprolactinaemia may implicate a nondialyzable substance acting at the lactotrophes to block the normal dopaminergic inhibition of prolactin release ( $\mathrm{Ho}$ et al, 1985).

The post receptor events that cause prolactin release remain incompletely defined. Several messenger systems appear to play an integral role. Recent evidence suggests that both calcium and CAMP provoke prolactin release. Specifically stimulation of adenylate cyclase may be calcium dependent. Thus, stimulation of the dopaminergic receptors on the lactotrophe membrane may inhibit calcium and CAMP activity which in turn inhibits prolactin release (Cronin \& Evans,1983).

Vol. 22, No. 1 \& 2 Jan. \& April 1992
The mechanism through which hyperprolactinaemia exerts its hypoyonadal effects may occur at the level of gonads, pituitary or hypothalamus (Evans et al, 1982). The suggestion of a direct antagonistic effect of prolactin on the gonads must be interpreted cautiously since hyperprolactinaemia may act indirectly through hypothalamus and/or pituitary glands (Evans \& Thorner, 1984).

As for serum zinc, there is a highly significant reduction in its level in chronic renal failure patients. The exact aetiology of this reduction is unknown and may be multifactorial including decreased dietary protein intake (Blendis et al, 1981), leaching of zinc by dialysis equipment and zinc malabsorption (Smith \& DeFronzo, 1984).

Oral zinc administration for four months, in a dose of $400 \mathrm{mg}$ zinc sulphate (equivalent to $5 \mathrm{mEq}$ zinc) per day, causes a higly significant increase in serun zinc level. At the same time, it causes a highly signifi- 
cant decrease in serum prolactin level and improvement in sexual functions.

The fact that zinc administration decreases serum prolactin level in hyperprolactinaemic patients suggests that zinc may be involved in the control of prolactin release as proved in previous in vitro studies which showed that zinc is a potent inhibitor of prolactin release from pituitary lactotrophes (Login et al, 1983; Judd et al,1984). The exact mechanism by which zinc decreases prolactin level in hyperprolactinaemic patients is not known, it may act by increasing synthesis, release, or transport of dopamine which is a potent inhibitor of prolactin release. It may enhance dopamine binding to its receptors on the lactotrophes membranes, or it may act on a postreceptor event inhibiting a calcuim dependent CAMP release.

The improvement in sexual functions which occurs after zinc administration may be attributed to lowering of prolactin level with the return of the nadotropin pulsatility that was alty decreased or abolished in hy- perprolactinaemia (Evans \& Thorner, 1984).

\section{SUMMARY AND CONCLUSION}

Hyperprolactinaemia and low serum zinc levels are common findings in chronic renal failure ptients.

In this study, fourteen chronic renal failure men on chronic haemodialysis were given $400 \mathrm{mg}$ zinc sulphate (equivalent to $5 \mathrm{mEq}$ zinc) per day for four months Serum prolactin and zinc levels were measured before and after oral zinc administration.

Statistical analysis of the results revealed a highly significant decrease $(P$ $<0.001$ ) in serum prolactin level after zinc administration $(20.01 \pm 16$ vs $31.74 \pm 2.61 \mathrm{ng} / \mathrm{ml})$. On the other hand, a highly significant increase $(P<$ 0.001 ) in serum zinc level was found after zinc administration $(16.96 \pm 0.86$ vs $10.03_{ \pm} 0.47 \mathrm{mEq} / \mathrm{L}$ ). Also, a marked improvement in sexual function was found.

So, chronic oral zinc administration may be important in the treatment of MANSOURA MEDICAL JOURNAL 
hyperprolactinaemia in chronic renal of importance in treatment of hyperfailure men with its sequele as impo- prolactinaemia with its sequele of sextence, diminished libido, gynaecomas- ual dysfunctoin as diminished libido, tia and infertility since zinc may play impotence, gynaecomastia and inferan important role in inhibition of pro- tility. lactin sacretion by pituitary lactotrophes.

\section{ACKNOWLEDGEMENT}

The authers are grateful to Dr. Ali

On conclusion, this study suggests Saker, Specialist in internal medicine that chronic zinc administration in in Mit-Ghamer General Hospital for his chronic renal failure patients may be co-operation.

Vol. 22, No. 1 \& 2 Jan. \& April 1992 
Hafez, T. A.; et al...

Table (1) : Serum prolactin level $(\mathrm{ng} / \mathrm{ml})$ in control group and chronic renal failure (CRF) group before and after zinc administration.

\begin{tabular}{|llll|}
\hline Item & Control group & $\begin{array}{l}\text { CRF before } \\
\text { zinc adm. }\end{array}$ & $\begin{array}{l}\text { CRF after } \\
\text { zinc adm. }\end{array}$ \\
\hline Range & $6.2 \cdot 22.4$ & $15.9-52.9$ & $10.2-29.7$ \\
Mean & 15.87 & 31.74 & 20.01 \\
SEM & \pm 1.29 & \pm 2.61 & \pm 1.6 \\
$T$ & & 5.44 & 2.01 \\
$P$ & & $<0.001$ & $<0.05$ \\
\hline
\end{tabular}

Table (2) : Serum zinc level (umol/L) in control group and chronic renal failure (CRF) group before and after zinc administration.

\begin{tabular}{|llll|}
\hline Item & Control group & $\begin{array}{l}\text { CRF before } \\
\text { zinc adm. }\end{array}$ & $\begin{array}{l}\text { CRF after } \\
\text { zinc adm. }\end{array}$ \\
\hline Range & $11.4-25.2$ & $7.2-13.4$ & $11.9-22.6$ \\
Mean & 18.28 & 10.03 & 16.96 \\
SEM & \pm 1.09 & \pm 0.47 & \pm 0.86 \\
$T$ & & 6.95 & 0.98 \\
$P$ & & $<0.001$ & $>0.05$ \\
\hline
\end{tabular}

Table (3) : Serum prolactin level (ng/ml) in chronic renal failure (CRF) group before and after zinc administration (paired student's $\mathrm{t}$ ).

\begin{tabular}{|lll|}
\hline Item & $\begin{array}{c}\text { CRF before } \\
\text { zinc adm. }\end{array}$ & $\begin{array}{l}\text { CRF after } \\
\text { zinc adm. }\end{array}$ \\
\hline Range & $15.9-52.9$ & $10.2-29.7$ \\
Mean & 31.74 & 20.01 \\
SEM & \pm 2.61 & \pm 1.6 \\
Difference & & -11.72 \\
SE of difference & & 1.24 \\
$T$ & & 9.47 \\
$P$ & & $<0.001$ \\
\hline
\end{tabular}


Table (4) : Serum zinc level (umol/L) in chronic renal failure (CRF) group before and after ziric administiation (paired student's $t$ ).

\begin{tabular}{|lll|}
\hline Item & $\begin{array}{l}\text { CRF before } \\
\text { zinc adm. }\end{array}$ & $\begin{array}{l}\text { CRF after } \\
\text { zinc adm. }\end{array}$ \\
\hline Range & $7.2-13.4$ & $11.9-22.6$ \\
Mean & 10.03 & 16.96 \\
SEM & \pm 0.47 & \pm 0.86 \\
Difference & & 6.93 \\
SE of difference & & 0.64 \\
$T$ & & 10.77 \\
$P$ & & $<0.001$ \\
\hline
\end{tabular}

Table (5) : Symptoms of gonadal dysfunction in chronic renal failure men before and after zinc administration.

\begin{tabular}{|lccc|}
\hline \multicolumn{1}{|c}{ Item } & $\begin{array}{c}\text { No. of patients } \\
\text { having symp- } \\
\text { toms before } \\
\text { zinc ad. }\end{array}$ & $\begin{array}{c}\text { No. of pa- } \\
\text { tients im- } \\
\text { proved } \\
\text { after zinc ad. }\end{array}$ & $\begin{array}{c}\text { Percent of } \\
\text { improvement }\end{array}$ \\
\hline Diminished libido & 14 & 11 & $78.6 \%$ \\
$\begin{array}{l}\text { Decreased frequency } \\
\text { of intercourse }\end{array}$ & 14 & 12 & $85.7 \%$ \\
Impotence & 9 & 5 & $55.5 \%$ \\
Gynaecomastia & 3 & 1 & $33.3 \%$ \\
Infertility & Not studied because of the short period of the \\
& work. & & \\
\hline
\end{tabular}

Vol. 22, No. 1 \& 2 Jan. \& April 1992 
Hafez, T. A.; et al...

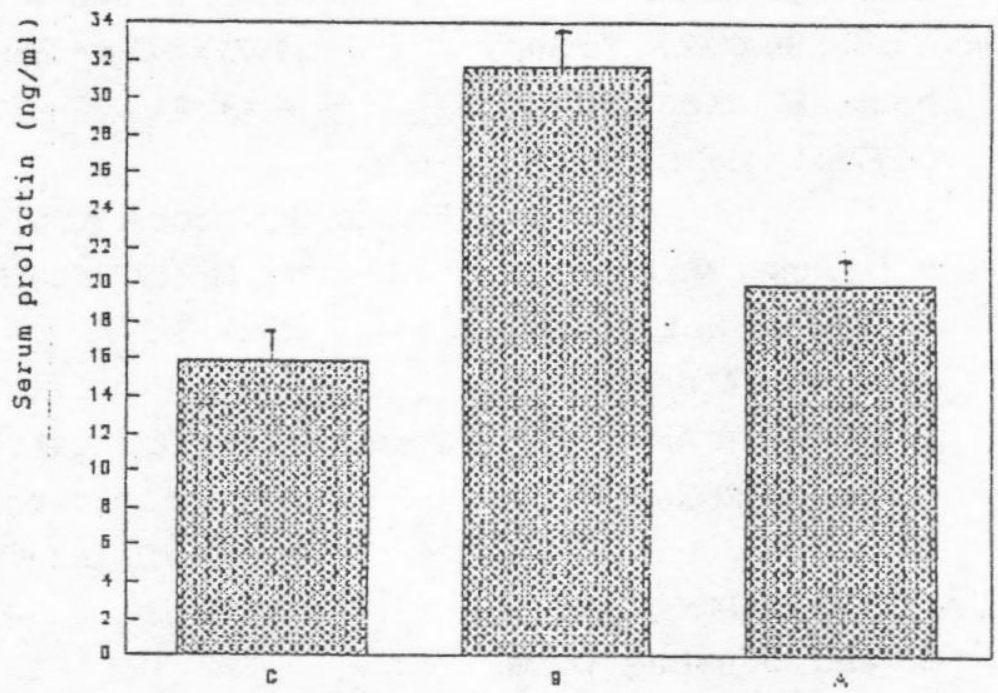

Eigure 1: Serum prolactin (ng/ml) level in control group (C) and chronic renal failur group before (B) and after (A) oral zinc

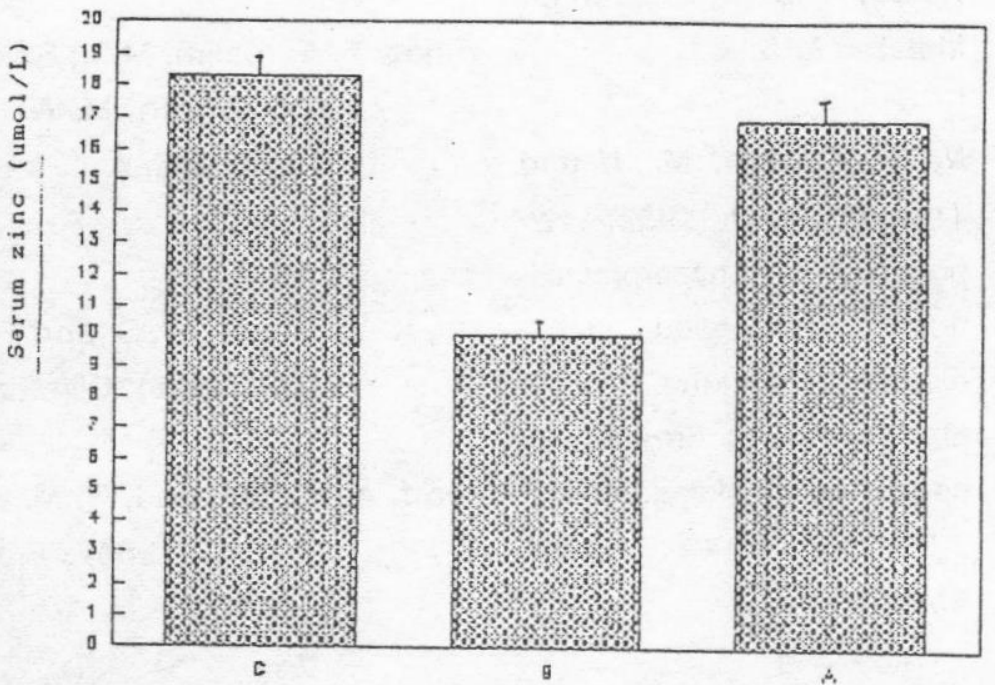
Pigure 2: Serum zinc (umol/L) level in control group (C) and chronic
$\begin{array}{llll}\text { renal failur group before } & \text { (B) and after (A) oral zinc } \\ \text { administration. }\end{array}$ 
REFERENCES

Antoniou, L. D.; Sudhakar, T.; Shalhoub, R. and Smith, J. (1977) : Lancet 2: 895-898.

Blendis, M. L ; Ampil, M.; Wilson, D. R ; Kiwan, J.; Labranche, J.; Jonson, M and William, S. C. (1981): Am. J. Clin. Nutrition 34: 2658-2661.

Brook, A. C.; Ward, M.K.; Cook, D. B. and Jonstan, D. G. (1980) : Lancet 2: 618-620.

Cronin, M. J. and Evans, W. S. (1983) : Clin. Endocrinol. Metab. 12:15.

Evans, W. S.; Cronin, M. J. and Thorner, M. O. (1982) : Hypogonadism in hyperprolactinaemia : proposed mechanisms. In : Ganong, W. F. \& Martini, L. eds Frontiers in neuroendocrinology, Vol 7, P 77, New York : Raven Press.

Evans, W. S. and Thorner, M. O. Lim, V. S.; Henriques, C. and Sie(1984) : Reprod. Endocrinol. $2: 9$.

Vol. 22, No. 1 \& 2 Jan. \& April 1992
Fernandez, F. J. and Khan, H. I. (1971) : Clin. Chem. Newslett. $3: 24$.

Franks, S.; Jacobs, H. S. and Martin, N. (1978) : Clin. Endocrinol . 8: 277 .

Gomez, F.; de la Cuva, R.; Wauters, J. P. and Lemarchand - Beraud, T. (1980) : Am. J. Med. 68: 522-530.

Gura, V.; Weizman, A.; Maoz, P.; Zevin, D. and Ben David, M. (1980) : Nephron . 26: 53-54.

Hafaz, T. A., Selim, M. I.; Said, M. A. and Zahran, M. A. (1990) : New Egyptian J. Med . 4/5: 1683-1686 .

Ho, K. Y.; Evans, W. S. and Thorner, M. O. (1985): Clin. Endocrinol Metab. 14 (1): 1.

Judd, A. M.; McLeod, R. M. and Login, I. S. (1984) : Brain Res. $294: 190$. vertsen, G. (1980) : Ann. Inter. Med. $93: 21.101$. 
Lim, V. S.; Kathpalia, S. C. and Smith, D. and Defronzo, R. A. Frohman, L. A. (1979) : J. Clin Endocrinol. Metab. 48: 101.

Login, I. S.; Thorner, M. O. and McLeod, R. M. (1983): Nauroendocrinology. $37: 317$.

Mahajan, S. K.; Abbasi, A. A.; Prasad, A. S. and Rabbani, P. (1982) : Ann. Inter . Med. 97: 357-361. (1984) : Endocrine dysfunction in chronic renal failure. In: Clinical dialysis. Nissenson, A. R.; Fine. R. N. and Gentile, D. E. (eds.), ACC/ Norwalk, Connecticut, California, p. 451.

Thorner, M. O. \& Besser, G. M. (1987) : Acta Endocrinol. 88: 131.

Werber, R. F.; Lamberts, S. W.; Mahajan, S. K.; Hamburger, R. J.; Flamenbaum, W.; Prasad, A. S. and McDonald, $F$ (1985) : Lancet 2: 750.

Mahajan, S. K.; Prasad, A. S.; Rabbani, P.; Briggs, W. A. and McDonald, F. (1979): J. Lab. Clin. Med. g4: 693-698.

Sievertgen, G. D.; Lim, V. S.; Nakawatase, C. and Frohman, Zetin, M. and Stone, R. A. (1980) : L. A. (1980) : J . clin. EndoClin. Nephrol. $13:$ 20-25. crinol Metab. 5: 846-852. Vreeburg, J. T. and Birkenhager, J. C. (1985) : Male hypogonadism and prolactin secretory adenomas. In : MacLeod, R. M.; Thorner, M. O. and Scapagnini, U. eds. Prolactin : basic and clinical correlates. Fidia Research Seris. Vol 1. P 745. New York : Springer-Velag Press. 


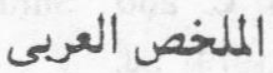

تأثير تعاطى الزنك بالفم على مستوى هرمون البرولاكتين فى مصل

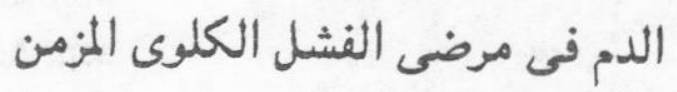

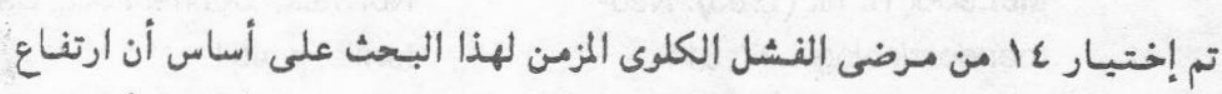

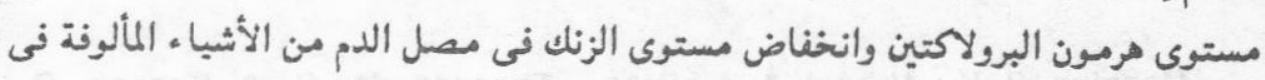

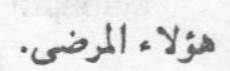

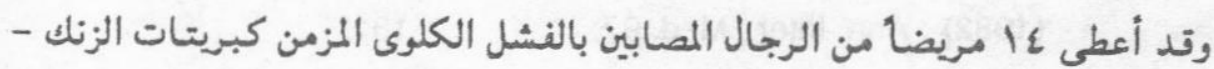

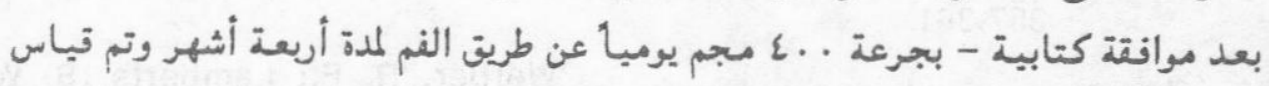



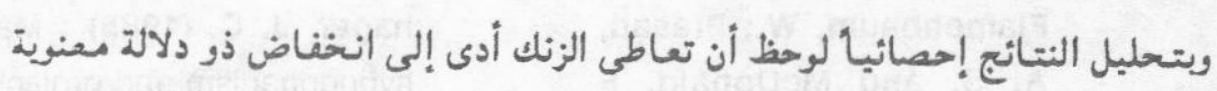

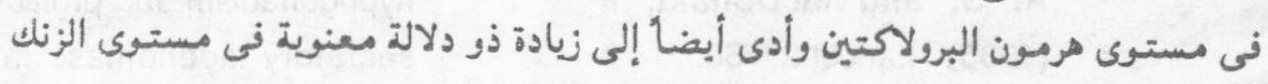

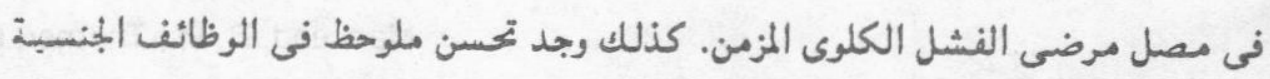
بعد تعاطى الزنك.

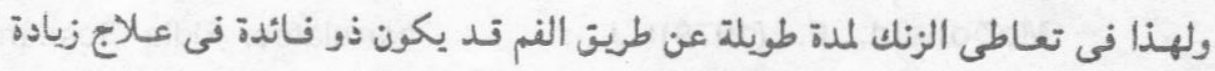

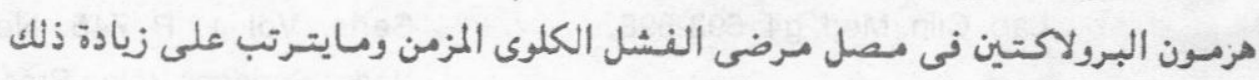
الهرمون من قصور فى الوظائف الجنسبة والعقم.

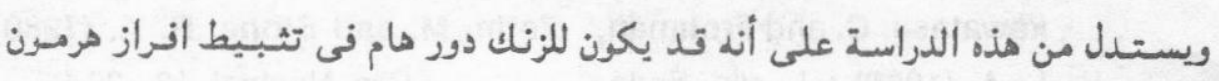
البرولاكتين من خلايا الغدة النخامية.

Vol. 22, No. 1 \& 2 Jan. \& April 1992 